\title{
PENGARUH CORPORATE GOVERNANCE DAN PROFITABILITAS TERHADAP TAX AVOIDANCE
}

\author{
Meila Sari ${ }^{1)}$, Heidy Paramitha Devi ${ }^{2)}$ \\ Program Studi Akuntansi, Universitas PGRI Madiun \\ msriwool@gmail.com \\ heidypd88@gmail.com
}

\begin{abstract}
This study aims to determine the effect of corporate governance and profitability to tax avoidance. Tax avoidance in this study is measured by Cash Effective Tax Rate. His study used a sample of mining companies listed on the Indonesia Stock Exchange during 2010-2015 using purposive sampling method. The method of analysis used is multiple regression analysis. The results of this study indicate that the proxy of corporate governance namely institutional ownership and independent board of commissioner influence tax avoidance. The results also show that tax avoidance is not influenced by the audit committee and audit quality. The results of profitability studies proxied with Return on Assets show that profitability affects tax avoidance.
\end{abstract}

Keywords: cash effective tax rate corporate governance, profitability, and tax avoidance.

\begin{abstract}
Abstrak
Penelitian ini bertujuan untuk mengetahui pengaruh corporate governance dan profitabilitas terhadap tax avoidance. Penghindaran pajak dalam penelitian ini diukur dengan Cash Effective Tax Rate. Penelitian ini menggunakan sampel perusahaan pertambangan yang terdaftar di Bursa Efek Indonesia selama tahun 2010-2015 dengan menggunakan metode purposive sampling. Metode analisis yang digunakan adalah analisis regresi berganda. Hasil penelitian ini menunjukkan bahwa proksi corporate governance yaitu kepemilikan institusional dan dewan komisaris independen berpengaruh terhadap tax avoidance. Hasil penelitan ini juga menunjukkan bahwa tax avoidance tidak dipengaruhi oleh komite audit dan kualitas audit. Hasil penelitian profitabilitas yang diproksikan dengan Return on Assets menunjukkan bahwa profitabilitas berpengaruh terhadap tax avoidance.
\end{abstract}

Kata Kunci: cash effective tax rate, corporate governance, profitabilitas, dan tax avoidance.

\section{PENDAHULUAN}

Berdasarkan Undang-Undang Nomor 16 Tahun 2009 tentang Ketentuan Umum Perpajakan Pasal 1 Ayat (1) menjelaskan bahwa : "Pajak adalah kontribusi wajib kepada negara yang terutang oleh orang pribadi atau badan yang bersifat memaksa berdasarkan UndangUndang, dengan tidak mendapatkan imbalan secara langsung dan digunakan untuk keperluan negara bagi sebesar-besarnya kemakmuran rakyat"

Proses pengembangan dan pembangunan negara membutuhkan penerimaan pajak yang tinggi sehingga pemerintah berupaya mengoptimalkan penerimaan pajak tidak terlepas dari beberapa kendala, terlebih lagi sistem perpajakan di Indonesia menganut sistem self assessment yang berarti bahwa sistem pemungutan pajak yang memberikan tanggung jawab kepada para wajib pajak untuk menghitung, membayar, dan melaporkan sendiri jumlah pajaknya sesuai dengan peraturan perundang-undangan perpajakan.

Hal ini menyebabkan banyaknya praktik penghindaran pajak (tax avoidance) yang dilakukan oleh wajib pajak. Penghindaran pajak (tax avoidance) didefinisikan sebagai salah satu tindakan yang dilakukan wajib pajak untuk mengurangi beban pajaknya secara legal yang tidak melanggar peraturan perpajakan. 
Penghindaran pajak dikatakan persoalan yang rumit dan unik karena disatu sisi dianggap tidak melanggar hukum, tetapi disisi lain tidak diinginkan karena merugikan negara dari segi penerimaan negara (Nandasari, 2015).

Fenomena penghindaran pajak di Indonesia, pada tahun 2007 Ditjen Pajak menemukan dugaan manipulasi pajak sebesar Rp2,1 triliun yang dilakukan tiga perusahaan grup bakrie yaitu Bumi Resources Tbk, PT Kaltim Prima Coal (KPC), dan PT Arutmin Indonesia (www.hukumonline.com).

Berdasarkan berita online pada tahun 2016 data pajak yang disampaikan oleh Koordinator Sumber Daya Alam (SDA) Direktorat Litbang KPK Dian Patria mengatakan, perusahaan yang bergerak di bidang pertambangan rata-rata menghindari pajak atau mengemplang pajak. Dari data 11.000 izin tambang ada 4000 yang non clean and clear, izin tumpang tindih dan sebagian besar tidak membayar pajak (www.klinikpajak.co.id).

Penelitian yang dilakukan Ginting (2016) penghindaran pajak (tax avoidance) dapat dipengaruhi oleh tata kelola perusahaan atau yang dikenal dengan corporate governance. Menurut Organization for Economic Cooperation and Development (dalam Fadhilah, 2014), corporate governance sendiri merupakan suatu sistem untuk mengarahkan dan mengendalikan perusahaan. Penelitian yang dilakukan oleh Sartori (dalam Winata, 2014) menjelaskan bahwa apabila suatu perusahaan memiliki suatu mekanisme corporate governance yang terstruktur dengan baik maka akan berbanding lurus dengan kepatuhan dalam memenuhi kewajiban perpajakannya.
Berdasarkan masalah diatas maka peneliti tertarik untuk meneliti pengaruh corporate governance yang diproksikan dengan kepemilikan institusional, presentase dewan komisaris independen, komite audit dan kualitas audit terhadap praktik tax avoidance.

Selain corporate governance, peneliti akan menganalisis mengenai keterkaitan profitabilitas terhadap tax avoidance. Return On Asset (ROA) merupakan salah satu rasio profitabilitas. Rasio ini paling sering disoroti dalam analisis laporan keuangan karena mampu menunjukkan keberhasilan perusahaan dalam menghasilkan keuntungan. Return On Asset (ROA) digunakan untuk mengukur kemampuan perusahaan dalam menghasilkan laba berdasarkan aset yang dimiliki. Semakin tinggi nilai Return On Asset (ROA), maka semakin besar juga laba yang diperoleh perusahaan (Dewinta dan Setiawan, 2016).

Penelitian ini berbeda dengan penelitian terdahulu karena sampel yang digunakan adalah perusahaan di sektor pertambangan yang terdaftar di Bursa Efek Indonesia selama periode 2010 hingga 2015. Penelitian ini, variabel penghindaran pajak diproksikan dengan CETR (Cash Effective Tax Rate). CETR (Cash Effective Tax Rate) yaitu kas yang dikeluarkan untuk biaya pajak dibagi dengan laba sebelum pajak. Menurut Dyreng et, al (dalam Zuesty, 2016) penggunaan pengukuran CETR (Cash Effective Tax Rate) dalam mengukur tax avoidance baik digunakan untuk menggambarkan kegiatan penghindaran pajak oleh perusahaan karena CETR (Cash Effective Tax Rate) tidak terpengaruh dengan adanya perubahan estimasi seperti 


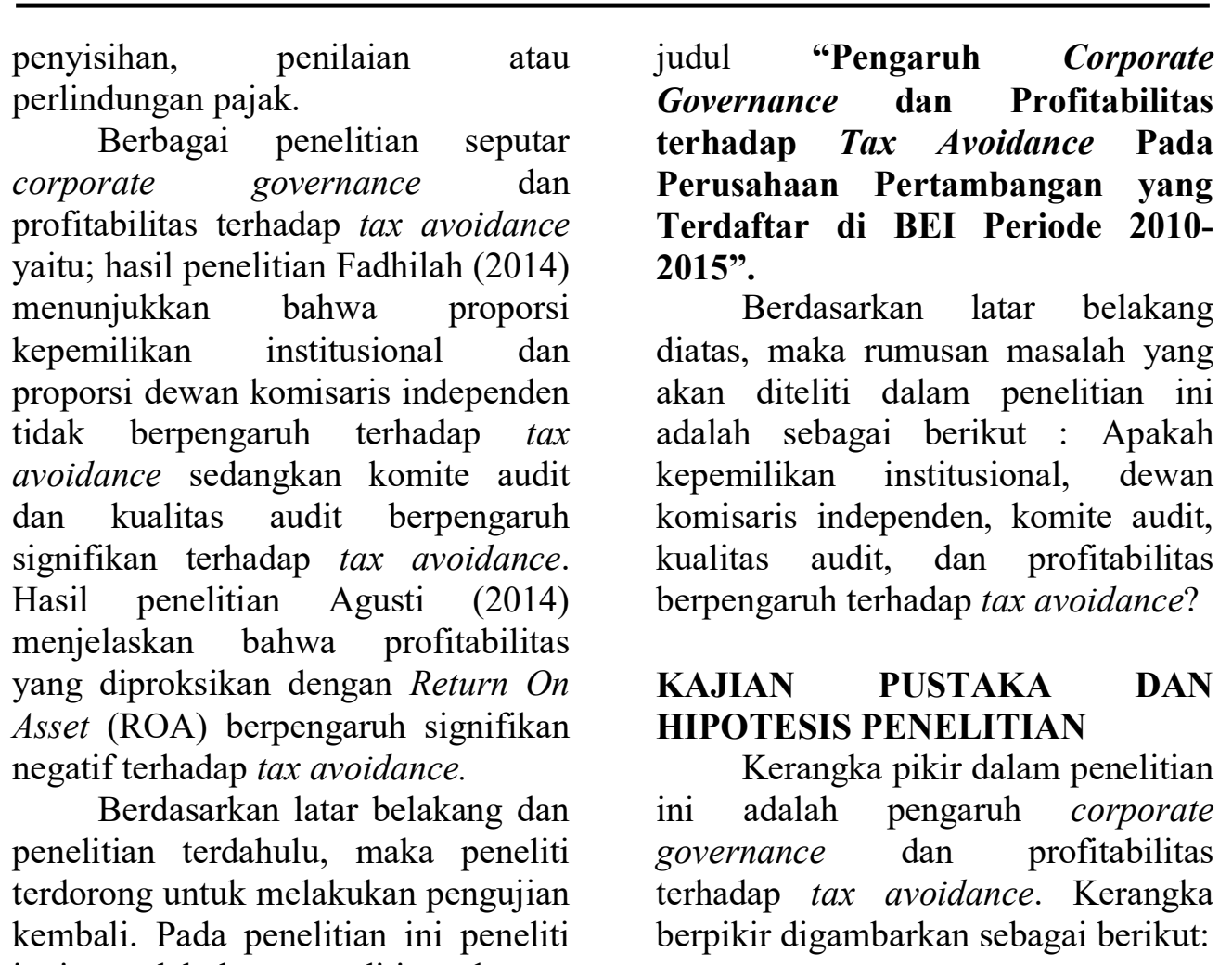
ingin melakukan penelitian dengan

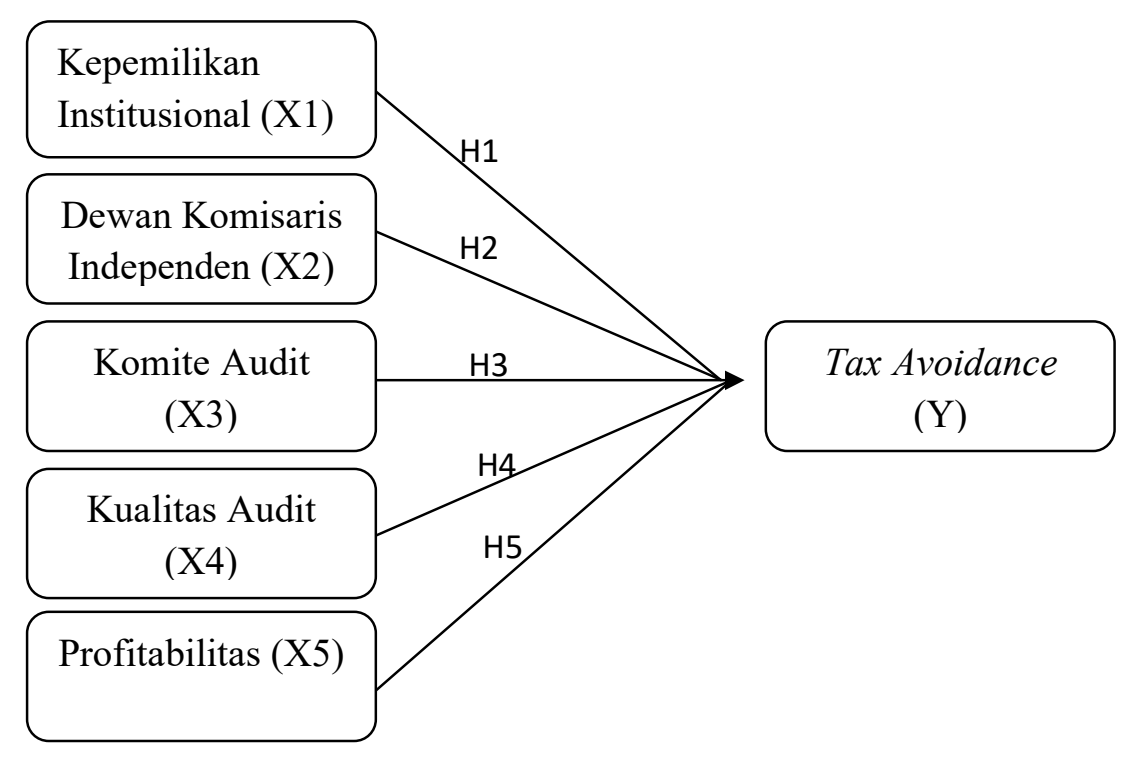

Hipotesis dalam penelitian ini sebagai berikut:

H1 : Kepemilikan institusional berpengaruh terhadap tax avoidance

$\mathrm{H} 2$ : Dewan komisaris independen berpengaruh terhadap tax avoidance

H3 : Komite audit berpengaruh terhadap tax avoidance

H4 : Kualitas audit berpengaruh terhadap tax avoidance

H5 : Profitabilitas berpengaruh terhadap tax avoidance 


\section{METODE PENELITIAN}

Penelitian ini bertujuan untuk menganalisis hubungan kausalitas yang digunakan untuk menjelaskan pengaruh variabel independen yaitu corporate governance dan profitabilitas terhadap variabel dependen penghindaran pajak (tax avoidance). Objek penelitian ini adalah perusahaan sektor pertambangan yang terdaftar di Bursa Efek Indonesia (BEI) periode 20102015. Data diperoleh melalui laporan keuangan tahunan perusahaan yang dapat diakses di www.idx.com.

Populasi dalam penelitian ini adalah perusahaan Go Public yang tercatat dalam Bursa Efek Indonesia sektor pertambangan periode 20102015 sebanyak 41 perusahaan. Pemilihan sampel menggunakan metode purposive sampling yaitu teknik penentuan sampel dengan pertimbangan tertentu (Sugiyono, 2010: 96). Sampel dipilih berdasarkan karakteristik tertentu. Adapun kriteria pemilihan sampel dalam penelitian ini sebagai berikut :

1. Perusahaan pertambangan yang terdaftar di BEI dan tidak mengalami delisting selama periode pengamatan dari tahun 2010 sampai 2015

2. Perusahaan yang secara berturut-turut melaporkan laporan keuangannya dari tahun 2010 sampai 2015

3. Laporan keuangan tahunan yang disajikan dalam bentuk mata uang rupiah

4. Perusahaan sektor pertambangan yang laba bersih sebelum pajaknya tidak mengalami kerugian selama tahun 2010 sampai 2015

Instrumen penelitian adalah suatu alat yang digunakan mengukur fenomena alam maupun sosial yang diamati. Secara spesifik semua fenomena ini disebut variabel penelitian (Sugiyono, 2010:119). Adapun instrumen penelitian sebagai berikut:

1) Instrumen untuk mengukur Kepemilikan Institusional Sujoko (dalam Fadhilah, 2014) menjelaskan kepemilikan institusional merupakan proporsi kepemilikan saham oleh institusi pendiri perusahaan, bukan institusi pemegang saham publik yang diukur dengan persentase jumlah saham yang dimiliki oleh investor institusi intern. Kepemilikan institusional dapat diukur menggunakan rasio sebagai berikut:

Kepemilikan Institusional $=\frac{\text { Proporsi saham yang dimiliki institusi }}{\text { Jumlah saham yang diterbitkan }}$

2) Instrumen untuk mengukur Dewan Komisaris Independen

Komisaris Independen didefinisikan sebagai seorang yang tidak terafiliasi dalam segala hal dengan pemegang saham pengendali, tidak memiliki hubungan afiliasi dengan direksi atau dewan komisaris serta tidak menjabat sebagai direktur pada suatu perusahaan yang terkait dengan perusahaan pemilik menurut peraturan yang dikeluarkan oleh BEI 
(Cahyono dkk, 2016). Proporsi Dewan Komisaris Independen diukur dengan rasio sebagai berikut:

Komisaris Insdependen $=$ Jumlah anggota komisaris independen Jumlah seluruh anggota dewan komisaris

3) Instrumen untuk mengukur Komite Audit Menurut Tugiman (dalam Sarra, 2017) pengertian komite audit adalah sekelompok orang yang dipilih oleh kelompok yang lebih besar untuk mengerjakan pekerjaan tertentu atau untuk melakukan tugas-tugas khusus atau sejumlah anggota dewan komisaris perusahaan klien yang bertanggung jawab untuk membantu auditor dalam mempertahankan independennya dari manajemen. Komite audit dapat diukur dengan menggunakan rasio sebagai berikut:

$$
\text { Komite Audit }=\sum \text { Anggota komite audit di perusahaan }
$$

4) Instrumen untuk mengukur Kualitas Audit

Pengukuran kualitas audit berdasarkan besar kecilnya ukuran kantor akuntan publik yang melakukan audit pada suatu perusahaan. Perusahaan yang menggunakan jasa KAP The Big Four dalam mengaudit laporan keuangannya pada penelitian akan diberi nilai 1 , apabila tidak diaudit KAP The Big Four akan diberi nilai 0 (Dewi dan Sari, 2015).

5) Instrumen untuk mengukur Profitabilitas

Return On Asset (ROA) mengukur kemampuan perusahaan menghasilkan laba bersih berdasarkan tingkat aset yang tertentu. ROA sering juga disebut sebagai ROI (Return On Investment). Rasio tersebut bisa dihitung sebagai berikut:

$$
\text { Return On Asset }=\frac{\text { Laba Bersih }}{\text { Total Aset }}
$$

6) Instrumen untuk mengukur Tax Avoidance

Menurut Dyreng et, al (dalam Zuesty, 2016) penggunaan pengukuran CETR (Cash Effective Tax Rate) dalam mengukur tax avoidance baik digunakan untuk menggambarkan kegiatan penghindaran pajak oleh perusahaan karena
CETR (Cash Effective Tax Rate) tidak terpengaruh dengan adanya perubahan estimasi seperti penyisihan, penilaian atau perlindungan pajak. Rumus untuk menghitung CETR (Cash Effective Tax Rate) adalah sebagai berikut: 


$$
\text { CETR }=\frac{\text { Cash Tax Paid }}{\text { Pre }- \text { tax income }}
$$

Teknik analisis data bertujuan untuk mengetahui peran masingmasing variabel bebas dalam mempengaruhi variabel terikat. Sebelum melakukan analisis regresi ada beberapa syarat pengujian yang harus dipenuhi agar hasil olahan data benar-benar menggambarkan apa yang menjadi tujuan penelitian yaitu:

1. Statistik Deskriptif

2. Uji Asumsi Klasik yang meliputi:

Uji Normalitas, Uji

Multikolonieritas, Uji

Autokorelasi, Uji

Heteroskedastisitas

3. Analisis Regresi Berganda

4. Pengujian Hipotesis yang meliputi: Uji t (parsial) dan Uji

Koefisien Determinasi

\section{HASIL DAN PEMBAHASAN}

\section{Pengaruh Kepemilikan Institusional terhadap $\operatorname{Tax}$ Avoidance}

Berdasarkan hasil uji $t$ pada model regresi, variabel kepemilikan institusional $\left(\mathrm{X}_{1}\right)$ dengan tingkat signifikansi sebesar 0,005 kurang dari $0,05(0,005<0,05)$. Hal ini menunjukkan nilai signifikansi kurang dari 0,05 maka $\mathrm{H}_{0}$ ditolak dan $\mathrm{Ha}$ diterima, artinya secara parsial variabel kepemilikan institusional berpengaruh terhadap variabel tax avoidance pada perusahaan sektor pertambangan di BEI periode tahun 2010-2015.

Kepemilikan institusional memiliki arti penting dalam memonitor manajemen karena adanya institusional kepemilikan akan meningkatkan pengawasan yang lebih optimal karena dianggap mampu memonitor setiap keputusan yang diambil oleh para manajer secara efektif. Dengan tingginya tingkat kepemilikan institusional maka semakin besar tingkat pengawasan ke manajer dan dapat mengurangi konflik kepentingan antara manajemen sehingga masalah keagenan menjadi berkurang dan mengurangi peluang terjadinya penghindaran pajak (Winata, 2014).

2. Pengaruh Dewan Komisaris Independen terhadap $\operatorname{Tax}$ Avoidance

Berdasarkan hasil uji $t$ pada model regresi, variabel dewan komisaris independen $\left(\mathrm{X}_{2}\right)$ dengan tingkat signifikansi sebesar 0,033 kurang dari $0,05 \quad(0,033<$ 0,05). Hal ini menunjukkan nilai signifikansi kurang dari 0,05 maka $\mathrm{H}_{0}$ ditolak dan $\mathrm{Ha}$ diterima, artinya secara parsial variabel dewan komisaris independen berpengaruh terhadap variabel tax avoidance pada perusahaan sektor pertambangan di BEI periode tahun 2010-2015. Pohan (dalam Feranika,
2015) semakin tinggi presentase dewan komisaris independen berarti semakin banyak juga suatu perusahaan memiliki dewan komisaris independen, oleh karena itu independensi juga akan makin tinggi karena semakin banyak yang tidak ada kaitan secara langsung dengan pemegang saham pengendali, sehingga 
kebijakan tax avoidance dapat semakin rendah, dan begitu pula sebaliknya semakin rendah presentase dewan komisaris independen berarti semakin sedikit suatu perusahaan memiliki dewan komisaris independen, oleh karena itu independensi juga rendah, sehingga kebijakan tax avoidance semakin tinggi.

\section{Pengaruh Komite Audit terhadap Tax Avoidance}

Berdasarkan hasil uji $\mathrm{t}$ pada model regresi, variabel komite audit $\left(\mathrm{X}_{3}\right)$ dengan tingkat signifikansi sebesar 0,857 lebih besar dari 0,05 $(0,857>0,05)$. Hal ini menunjukkan nilai signifikansi lebih besar dari 0,05 maka $\mathrm{H}_{0}$ diterima dan $\mathrm{Ha}$ ditolak, artinya secara parsial variabel komite audit tidak berpengaruh terhadap variabel tax avoidance pada perusahaan sektor pertambangan di BEI periode tahun 2010-2015.

Dewi dan Sari (2015) kinerja komite audit tidak berjalan dengan baik meskipun jumlah komite audit pada perusahaan sudah sesuai dengan standar BEI, yaitu komite audit paling sedikit berjumlah 3 orang. Hal ini bisa juga disebabkan oleh cara pengukuran yang dilakukan dalam penelitian. Hasil tabulasi data untuk variabel komite audit cenderung homogen atau tidak bervariasi sehingga sulit untuk mengukur secara tepat pengaruh variabel komite audit pada tax avoidance.
4. Pengaruh Kualitas Audit terhadap Tax Avoidance

Berdasarkan hasil uji $t$ pada model regresi, variabel kualitas audit $\left(\mathrm{X}_{4}\right)$ dengan tingkat signifikansi sebesar 0,228 lebih besar dari 0,05 $(0,228>0,05)$. Hal ini menunjukkan nilai signifikansi lebih besar dari 0,05 maka $\mathrm{H}_{0}$ diterima dan $\mathrm{Ha}$ ditolak, artinya secara parsial variabel kualitas audit tidak berpengaruh terhadap variabel tax avoidance pada perusahaan sektor pertambangan di BEI periode tahun 2010-2015.

Winata (2014) yang menyatakan bahwa tidak ada perbedaan yang signifikan antara perusahaan yang diaudit oleh KAP The Big Four maupun KAP non The Big Four terhadap penanggulangan praktik tax avoidance, hal ini dikarenakan ketika KAP mengaudit suatu laporan keuangan berpedoman pada standart pengendalian mutu kualitas audit telah ditetapkan oleh Dewan Standar Profesional Akuntan Publik Indonesia (DSPAP IAPI) dan aturan etika akuntan publik yang ditetapkan oleh IAPI sehingga dalam pelaksanaannya sudah didasarkan pada auran yang ada.

5. Pengaruh Profitabilitas terhadap Tax Avoidance

Berdasarkan hasil uji $\mathrm{t}$ pada model regresi, variabel profitabilitas $\left(\mathrm{X}_{5}\right)$ dengan tingkat signifikansi sebesar 0,006 kurang dari $0,05(0,006$ $<0,05)$. Hal ini menunjukkan 
nilai signifikansi kurang dari 0,05 maka $\mathrm{H}_{0}$ ditolak dan $\mathrm{Ha}$ diterima, artinya secara parsial variabel profitabilitas berpengaruh terhadap variabel tax avoidance pada perusahaan sektor pertambangan di BEI periode tahun 2010-2015.

Apabila kemampuan perusahaan menghasilkan laba meningkat maka laba operasional perusahaan juga akan meningkat dan nilai pajak juga meningkat oleh karena inilah profitabilitas berpengaruh terhadap tax avoidance, tapi apabila laba meningkat penghindaran pajak menurun hal ini disebabkan oleh perusahaan tidak melakukan tindakan efisiensi dalam pembayaran pajaknya (Agusti, 2014).

\section{KESIMPULAN}

1. Kepemilikan Institusional berpengaruh terhadap Tax Avoidance

2. Dewan Komisaris Independen berpengaruh terhadap Tax Avoidance

3. Komite Audit tidak berpengaruh terhadap Tax Avoidance

4. Kualitas Audit tidak berpengaruh terhadap $\operatorname{Tax}$ Avoidance

5. Profitabilitas berpengaruh terhadap Tax Avoidance

\section{SARAN}

1. Penelitian selanjutnya dapat menggunakan pengukuran selain CETR (Cash Effective Tax Rate) dalam mengukur tax avoidance. Salah satu contohnya adalah dengan menggunakan pengukuran book tax gap (BTG).

2. Peneliti selanjutnya disarankan untuk menambahkan populasi perusahaan yang dijadikan sampel penelitian tidak hanya perusahaan sektor pertambangan saja tetapi juga jenis industri lainnya yang terdaftar di Bursa Efek Indonesia.

3. Penelitian selanjutnya disarankan untuk menambah atau mengganti variabel independen lain yang mungkin mempengaruhi tindakan tax avoidance seperti leverage, risiko perusahaan, deferred tax expense, dan kompensasi rugi fiskal.

4. Penelitian selanjutnya diharapkan dapat menggunakan perusahaan yang menggunakan mata uang selain rupiah dengan dikonversikan ke mata uang rupiah.

\section{DAFTAR PUSTAKA}

Agusti, Wirna Yola. (2014). Pengaruh Profitabilitas, Leverage, $\quad$ Corporate Governance Terhadap Tax Avoidance. Universitas Negeri Padang.

Cahyono, D.D., Andini, R., \& Raharjo, K. (2016). Pengaruh Komite Audit, Kepemilikan Institusional, Dewan Komisaris, Ukuran Perusahaan, Leverage, dan Profitabilitas Terhadap Tindakan Penghindaran Pajak. Jounal of Accounting, Volume 2 No. 2 Maret 2016.

Dewi, Gusti A.P. \& Sari, Maria M.R. (2015). Pengaruh Insentif 
Eksekutif, Corporate Risk dan Corporate Governance Pada Tax Avoidance. E-jurnal Akuntansi Universitas Udayana 13.1. (2015): 50-67.

Dewinta, Ida Ayu. R. \& Setiawan, Putu Ery. (2016). Pengaruh Ukuran Perusahaan, Umur Perusahaan, Profitabilitas, Leverage, dan Pertumbuhan Penjualan Terhadap Tax Avoidance. E-Jurnal Akuntansi Universitas Udayana Vol.14.3. Maret (2016): 1584-1613.

Fadhilah, Rahmi. (2014). Pengaruh Good Corporate Governance Terhadap Tax Avoidance. Universitas Negeri Padang.

Feranika, Ayu. (2015). Pengaruh Kepemilikan Institusional, Dewan Komisaris Independen, Kualitas Audit, Komite Audit, Karakter Eksekutif, dan Leverage Terhadap Tax Avoidance. Alumni Magister Ilmu Akuntansi Pascasarjana Universitas Jambi.

Ginting, Suriani. (2016). Pengaruh Corporate Governance dan Kompensasi Rugi Fiskal Terhadap Penghindaran Pajak dengan Ukuran Perusahaan sebagai Variabel Moderating. Program Studi Akuntansi STIE Mikroskil. Jurnal Wira Ekonomi Mikroskil Volume 6, Nomor 02, Oktober 2016.

Mardiasmo. (2016). Perpajakan Edisi Terbaru 2016. Yogyakarta: CV Andi.

Nandasari, Elna Arlina. (2015). Analysis of Effect of Corporate Governance of Tax Avoidance. Perbanas Surabaya.

Sarra, Hustna Dara. (2017). Pengaruh Konservatisme Akuntansi, Komite Audit, dan Dewan Komisaris Independen
Terhadap Penghindaran Pajak. Universitas Muhammadiyah Tangerang. Competitive, Vol.1 No.1, Januari-Juni 2017.

Sugiyono. (2010). Metode Penelitian Administrasi Dilengkapi Metode $R \& D$. Bandung: Alfabeta

Winata, Fenny. (2014). Pengaruh Corporate Governance Terhadap Tax Avoidance Pada Perusahaan yang Terdaftar di Bursa Efek Indonesia Tahun 2013. Universitas Kristen Petra. Tax \& Accounting Review, VOL. 4, No.1, 2014.

www.hukumonline.com

www.idx.com

www.klinik pajak.co.id 